\title{
Self-Activated Catalytic Sites on Nanoporous Dilute Alloy for High-Efficiency
}

\section{Electrochemical Hydrogen Evolution}

Yaqian Yu, ${ }^{\# \dagger}$ Kang Jiang, ${ }^{\# \dagger}$ Min Luo, ${ }^{\# !}$ Yang Zhao, ${ }^{\dagger}$ Jiao Lan, ${ }^{\dagger}$ Ming Peng, ${ }^{\dagger}$ Frank M.

F. de Groot, ${ }^{z}$ Yongwen Tan*†

${ }^{\dagger}$ College of Materials Science and Engineering, State Key Laboratory of Advanced Design and Manufacturing for Vehicle Body, Hunan University, Changsha, Hunan 410082, China

${ }^{\star}$ Department of Physics, Shanghai Polytechnic University, Shanghai 201209, China

${ }^{z}$ Inorganic Chemistry \& Catalysis, Debye Institute for Nanomaterials Science, Utrecht University, Universiteitsweg 99, 3584 CGUtrecht, The Netherlands.

\#These authors contributed equally to the work

*Correspondence to: tanyw@hnu.edu.cn 


\section{Calculation of the electrochemically active surface areas (ECSA)}

ECSA was calculated from the equation as follow:

$$
\operatorname{ECSA}=\frac{C_{d l}}{C_{s}}
$$

The electrochemical double layer capacitance $\left(C_{\mathrm{dl}}\right)$ was measured by $\mathrm{CV}$ curves at different scan rates (Figure S12) and the general specific capacitance $\left(C_{\mathrm{S}}\right)$ found to be $60 \mu \mathrm{F} \mathrm{cm}^{-2}$ in $1.0 \mathrm{M} \mathrm{KOH} .{ }^{1}$ The specific details are as follows:

$$
\begin{aligned}
& j_{E C S A}^{n p-I r_{70} N i_{30}}=\frac{4.44 \mathrm{mF} \mathrm{cm}^{-2}}{60 \mu F \mathrm{~cm}^{-2} \operatorname{per} \mathrm{cm}_{E C S A}^{2}}=74 \mathrm{~cm}_{E C S A}^{2} \\
& j_{E C S A}^{N i / n p-I r}=\frac{6.59 \mathrm{mF} \mathrm{cm}^{-2}}{60 \mu F \mathrm{~cm}^{-2} \text { per } \mathrm{cm}_{E C S A}^{2}}=109.83 \mathrm{~cm}_{E C S A}^{2} \\
& j_{E C S A}^{P t / C}=\frac{5.16 \mathrm{mF} \mathrm{\textrm {cm } ^ { - 2 }}}{60 \mu F \mathrm{~cm}^{-2} \text { per } \mathrm{cm}_{E C S A}^{2}}=86 \mathrm{~cm}_{E C S A}^{2} \\
& j_{E C S A}^{I r / C}=\frac{4.75 \mathrm{mF} \mathrm{cm}^{-2}}{60 \mu F \mathrm{~cm}^{-2} \text { per } \mathrm{cm}_{E C S A}^{2}}=79.17 \mathrm{~cm}_{E C S A}^{2}
\end{aligned}
$$

\section{Calculation of the mass activity and price activity}

In order to evaluate the mass activities of $n p-\operatorname{Ir}_{70} \mathrm{Ni}_{30}, \mathrm{Ni} / \mathrm{np}-\mathrm{Ir}, \mathrm{Ir} / \mathrm{C}$, and $\mathrm{Pt} / \mathrm{C}$, the activity values were normalized to $\mathrm{Ir}$ or Pt loading. The current density at an overpotential of $50 \mathrm{mV}$ (Figure $3 \mathrm{~b}$ ) were chosen to assess the mass activity. The specific details are as follows:

(1) In 1.0 M KOH:

$$
\begin{aligned}
& j_{\text {mass }}^{n p-I r_{70} N i_{30}}=\frac{j_{\text {area }}^{n p-I r_{70} N i_{30}}}{\text { mass }_{I r}}=\frac{9.8\left(\mathrm{~mA} \mathrm{~cm} \mathrm{~cm}^{-2}\right)}{20.24\left(\mathrm{ug} \mathrm{cm} \mathrm{cm}^{-2}\right)}=0.48 \mathrm{~A} \mathrm{mg}^{-1} \\
& j_{\text {mass }}^{N i / n p-I r}=\frac{j_{\text {area }}^{N i / n p-I r}}{\text { mass }_{I r}}=\frac{156.16\left(\mathrm{~mA} \mathrm{~cm} \mathrm{~cm}^{-2}\right)}{22.09\left(\mathrm{ug} \mathrm{cm} \mathrm{cm}^{-2}\right)}=7.07 \mathrm{~A} \mathrm{mg}^{-1} \\
& j_{\text {mass }}^{P t / C}=\frac{j_{\text {area }}^{P t / C}}{\text { mass }_{P t}}=\frac{15.23(\mathrm{~mA} \mathrm{~cm}-2)}{30.61\left(u g \mathrm{~cm}^{-2}\right)}=0.50 \mathrm{~A} \mathrm{mg}^{-1}
\end{aligned}
$$




$$
j_{\text {mass }}^{I r / C}=\frac{j_{\text {area }}^{I r / C}}{\text { mass } I r_{I r}}=\frac{2.71\left(\mathrm{~mA} \mathrm{~cm} \mathrm{~cm}^{-2}\right)}{30.61\left(\mathrm{ug} \mathrm{cm} \mathrm{cm}^{-2}\right)}=0.09 \mathrm{~A} \mathrm{mg}^{-1}
$$

(2) In $0.5 \mathrm{M} \mathrm{H}_{2} \mathrm{SO}_{4}$ :

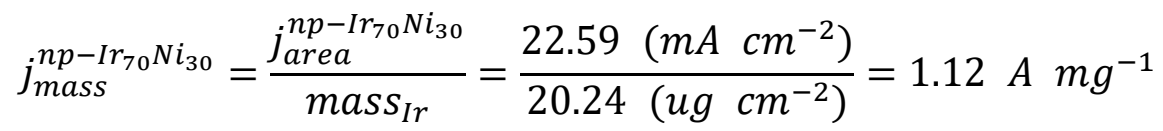

$$
\begin{aligned}
& j_{m a s s}^{N i / n p-I r}=\frac{j_{\text {area }}^{N i / n p-I r}}{\text { mass }_{I r}}=\frac{150.82\left(\mathrm{~mA} \mathrm{~cm} \mathrm{~cm}^{-2}\right)}{22.09\left(\mathrm{ug} \mathrm{cm} \mathrm{cm}^{-2}\right)}=6.83 \mathrm{~A} \mathrm{mg}^{-1} \\
& j_{\text {mass }}^{P t / C}=\frac{j_{\text {area }}^{P t / C}}{\text { mass }_{P t}}=\frac{38.85\left(\mathrm{~mA} \mathrm{~cm} \mathrm{~cm}^{-2}\right)}{30.61\left(u g \mathrm{~cm}^{-2}\right)}=1.27 \mathrm{~A} \mathrm{mg}^{-1} \\
& j_{\text {mass }}^{I r / C}=\frac{j_{\text {area }}^{I r / C}}{\text { mass }_{I r}}=\frac{12.35\left(\mathrm{~mA} \mathrm{~cm} \mathrm{~cm}^{-2}\right)}{30.61\left(\mathrm{ug} \mathrm{cm} \mathrm{cm}^{-2}\right)}=0.40 \mathrm{~A} \mathrm{mg}^{-1}
\end{aligned}
$$

For easy to compare, the activity values of the above samples were normalized to Ir or Pt price, respectively (Table S2). The specific details are as follows:

(1) In 1.0 M KOH:

$$
\begin{aligned}
& j_{\text {price }}^{n p-I r_{70} N i_{30}}=\frac{\text { mass } \text { activity }_{n p-I r_{70} N i_{30}}}{\text { price }_{I r}}=\frac{0.48\left(A \mathrm{mg}^{-1}\right)}{990 / 31.10\left(\text { dollar } \mathrm{g}^{-1}\right)} \\
& =15.08 A \text { dollar }^{-1} \\
& j_{\text {price }}^{N i / n p-I r}=\frac{\text { mass } \text { activity }_{N i / n p-I r}}{\text { price }_{I r}}=\frac{7.07\left(A \mathrm{mg}^{-1}\right)}{990 / 31.10\left(\text { dollar }^{-1}\right)} \\
& =222.10 \text { A dollar }{ }^{-1}
\end{aligned}
$$

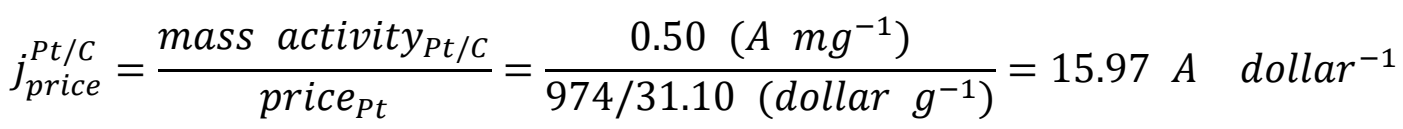

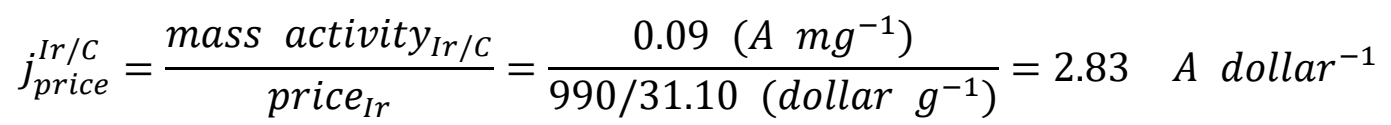




$$
\begin{aligned}
& j_{\text {price }}^{n p-I r_{70} N i_{30}}=\frac{\text { mass } \text { activity }_{n p-I r_{70} N i_{30}}}{\text { price }_{I r}}=\frac{1.12\left(A \mathrm{mg}^{-1}\right)}{990 / 31.10\left(\text { dollar }^{-1}\right)} \\
& =35.18 A \text { dollar }^{-1} \\
& j_{\text {price }}^{N i / n p-I r}=\frac{\text { mass } \text { activity }_{N i / n p-I r}}{\text { price }_{I r}}=\frac{6.83\left(\mathrm{~A} \mathrm{mg}^{-1}\right)}{990 / 31.10\left(\text { dollar }^{-1}\right)} \\
& =214.56 \text { A dollar }{ }^{-1} \\
& j_{\text {price }}^{P t / C}=\frac{{\text { mass } \text { activity }_{P t / C}}_{\text {price }_{P t}}}{9 \text { rich }}=\frac{1.27\left(\mathrm{~A} \mathrm{mg}^{-1}\right)}{97.10\left(\text { dollar }^{-1}\right)}=40.55 A \text { dollar }^{-1} \\
& j_{\text {price }}^{I r / C}=\frac{{\text { mass } \text { activity }_{\text {Ir } / C}}_{\text {price }_{\text {Ir }}}^{I r}}{990 / 31.10\left(\text { dollar }^{-1}\right)}=12.57 \mathrm{~A} \mathrm{dollar}^{-1}
\end{aligned}
$$

\section{Calculation of the active site density and turnover frequency (TOF):}

The active site density of Ir and Ni are estimated by using the reported method ${ }^{1}$ :

$$
\text { TOF }=\frac{\# \text { total } \text { hydrogen turnovers } / \text { geometric area }}{\text { \#surface sites } / \text { geometric area }}
$$

The number of total hydrogen turnovers are calculated from the current density according to:

Number of hydrogens

$$
\begin{gathered}
=\left(j \frac{m A}{c m^{2}}\right)\left(\frac{1 C s^{-1}}{1000 m A}\right)\left(\frac{1 \mathrm{~mol} e^{-1}}{96485.3 C}\right)\left(\frac{1 \mathrm{~mol} H_{2}}{2 m o l e^{-}}\right)\left(\frac{6.022 \times 10^{23}{\text { molecules } H_{2}}}{1 \mathrm{~mol} \mathrm{H}_{2}}\right) \\
=3.12 \times 10^{15} \mathrm{H}_{2} \mathrm{~s}^{-1} \mathrm{~cm}^{-2} \text { per } \mathrm{mA} \mathrm{cm} \mathrm{cm}^{-2}
\end{gathered}
$$

The active sites per real surface area are calculated from the following formula:

$$
\begin{gathered}
\text { \#surface sites }(\text { Ir })=\left(\frac{4 \text { atoms unit cell }}{56.60 \AA^{3} \text { unit cell }^{-1}}\right)^{\frac{2}{3}} \\
=1.709 \times 10^{15} \text { atoms } \text { cm }_{\text {real }}^{-2}
\end{gathered}
$$




$$
\begin{gathered}
\text { \#surface sites }(\mathrm{Ni})=\left(\frac{4 \text { atoms unit } \text { cell }^{-1}}{43.76 \AA^{3}{\text { unit } \text { cell }^{-1}}^{\frac{2}{3}}}\right)^{\frac{{ }^{3}}{4}} \\
=2.029 \times 10^{15} \text { atoms } \mathrm{cm}_{\text {real }}^{-2}
\end{gathered}
$$

Finally, the current density from the LSV polarization curves can be converted into the TOF values at different operation potentials according to:

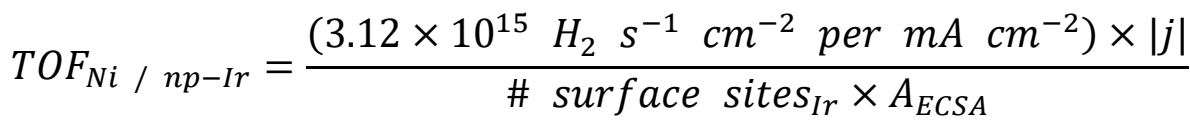

$$
\begin{aligned}
& T O F_{n p-I r_{70}} \mathrm{Ni}_{30}
\end{aligned}
$$

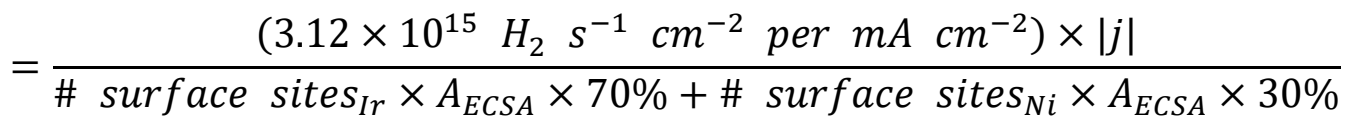

The TOF values of Ni/np-Ir and np- $\operatorname{Ir}_{70} \mathrm{Ni}_{30}$ were calculated and shown in Figure $\mathrm{S} 14$. 


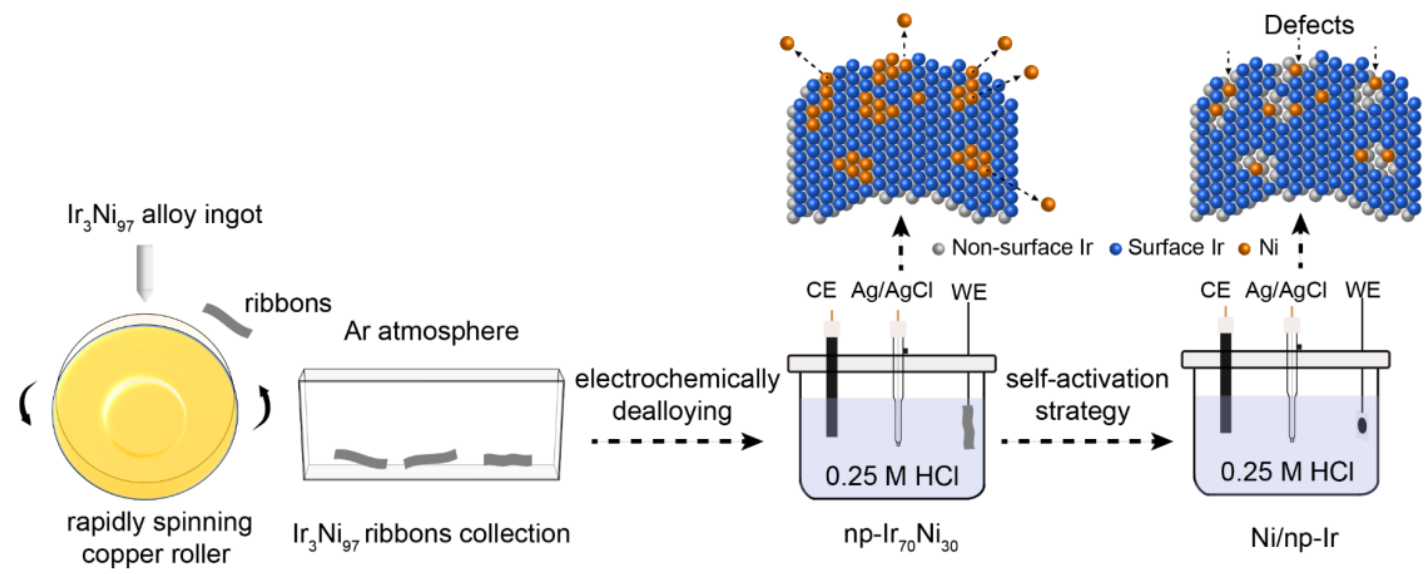

Figure S1. The process of preparing Ni/np-Ir. 

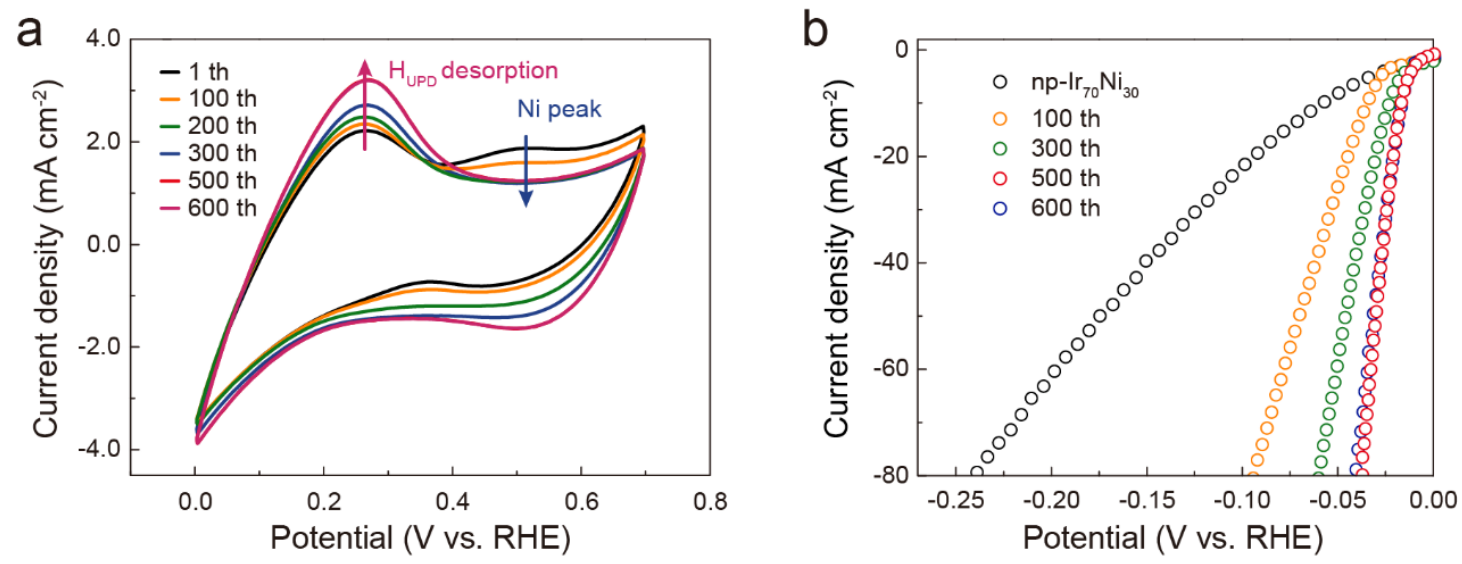

Figure S2. (a) CV curves and (b) HER polarization curves of np- $\mathrm{Ir}_{70} \mathrm{Ni}_{30}$ after different CV cycles in $0.25 \mathrm{M} \mathrm{HCl}$.

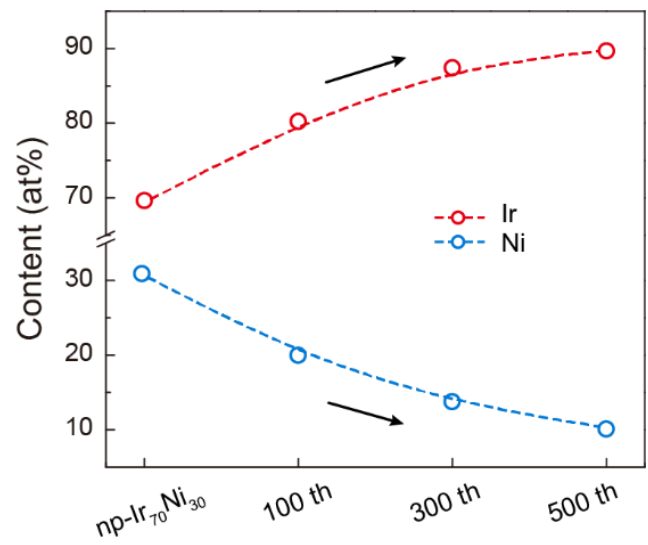

Figure S3. The composition of Ir and Ni in different samples obtained from the SEM energy-dispersive X-ray spectrometer (EDS) results. 

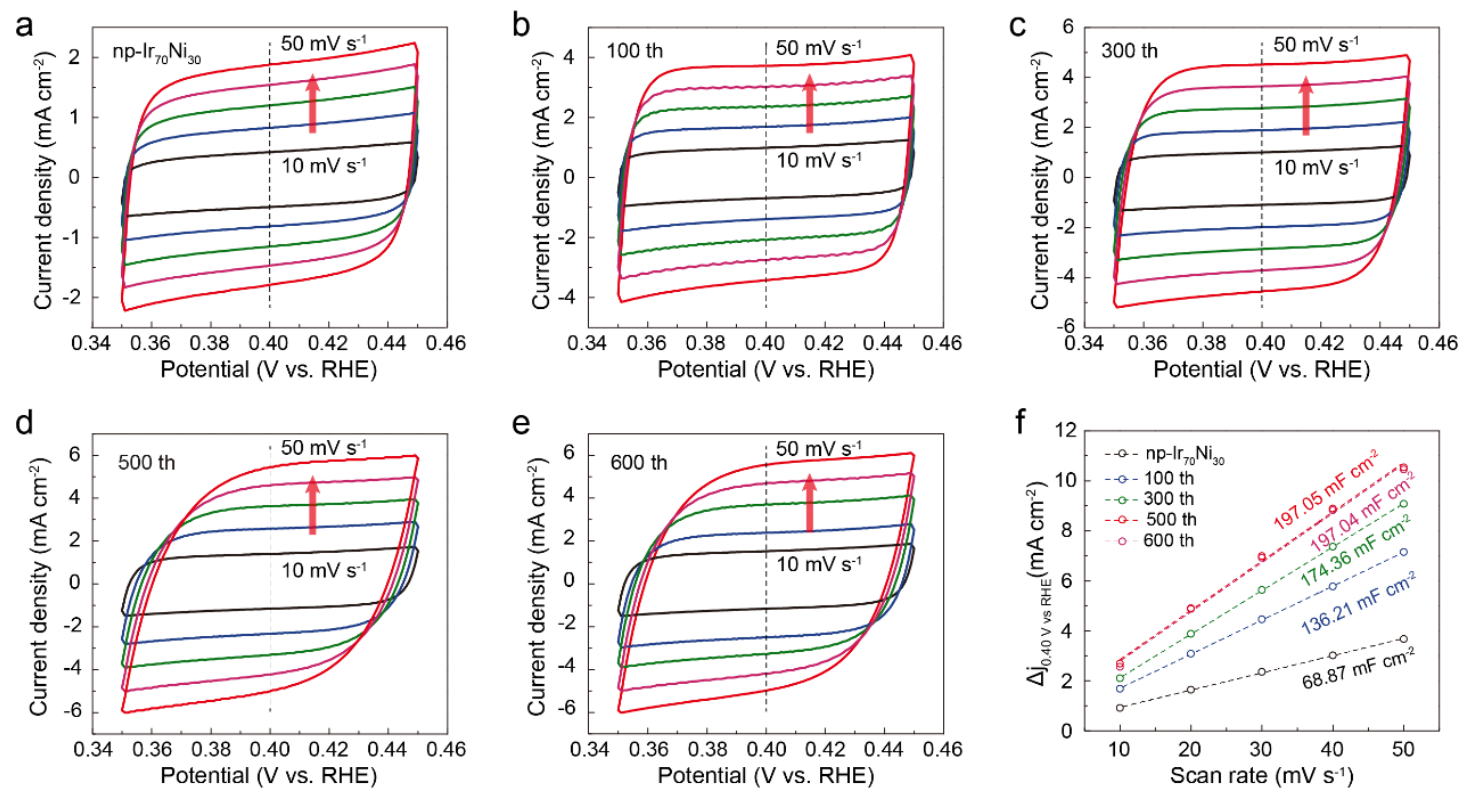

Figure S4. ECSA characterizations. (a-e) CV curves of different sample (as described in the "METHODS" Section). The scan rate of CV measurement was set to step from 10 to $50 \mathrm{mV} \mathrm{s}^{-1}$. (f) Corresponding $C_{\mathrm{dl}}$ measurements of different samples. The $\Delta j_{0.40}$ 
V versus RHE represents the difference between anodic and cathodic current densities at a potential of $0.40 \mathrm{~V}$ versus $\mathrm{RHE}$. The slopes of plots are equivalent to twice of the $C_{\mathrm{dl}}$. Note that the $\mathrm{CV}$ curves was measured by dropping different catalysts ink (without conductive carbon) on the clean surface of carbon cloth $(1 \mathrm{~cm} \times 1 \mathrm{~cm})$.

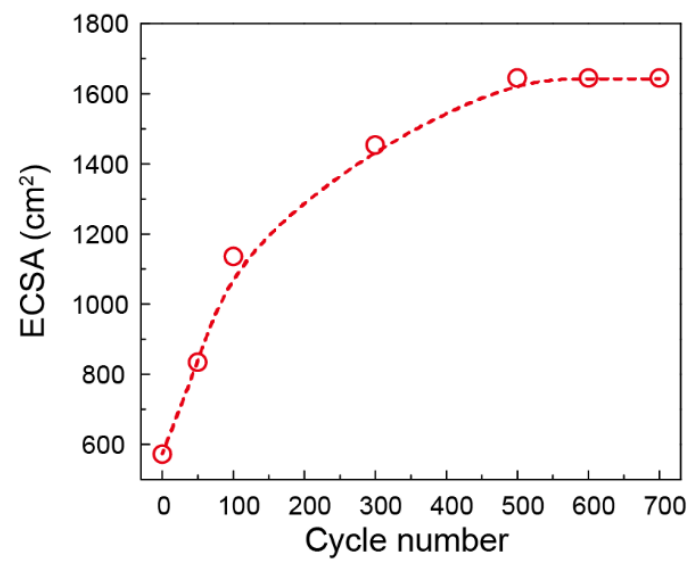

Figure S5. The ECSA evolution curve of $n p-\mathrm{Ir}_{70} \mathrm{Ni}_{30}$ after different $\mathrm{CV}$ cycles. 


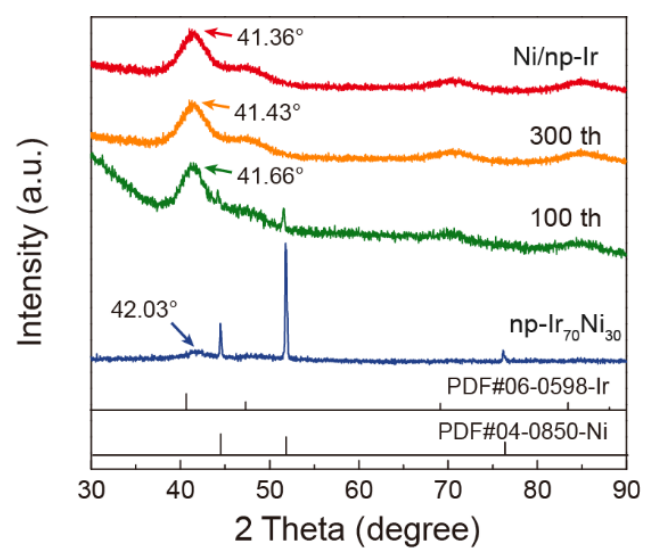

Figure S6. The XRD patterns of different sample (as described in the above materials synthesis). The JCPDS profiles of metallic Ni and Ir are showed as reference.

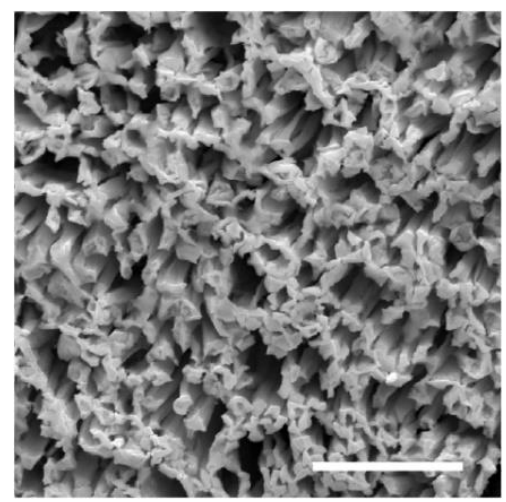

Figure S7. SEM characterization of Ni/np-Ir. Scale bar: $5 \mu \mathrm{m}$. 


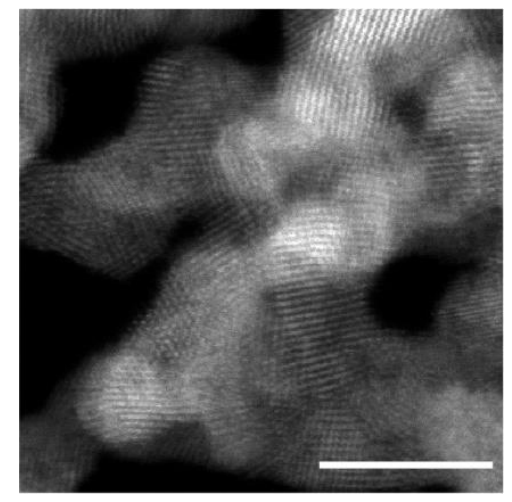

Figure S8. HAADF-STEM characterization of Ni/np-Ir. Scale bar: $5 \mathrm{~nm}$. 

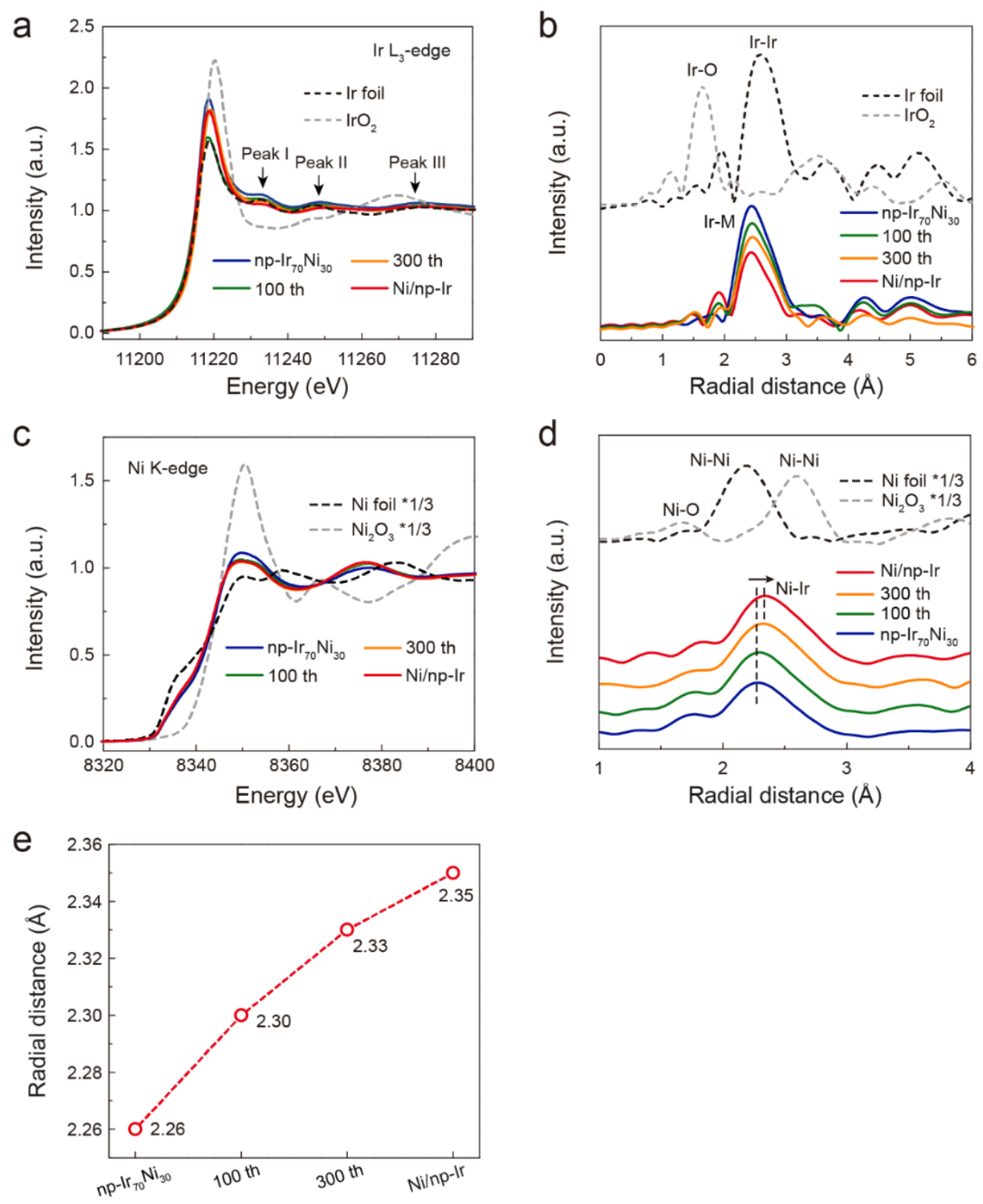

Figure S9. Structure characterizations of different catalysts. (a) The XANES spectra at the Ir $\mathrm{L}_{3}$-edge. (b) Corresponding FT-EXAFS spectra from (a). (c) The XANES spectra at the Ni K-edge. (d) Corresponding FT-EXAFS spectra from (c). (e) The radial distance of $\mathrm{Ni}$-Ir scattering feature for different samples. 

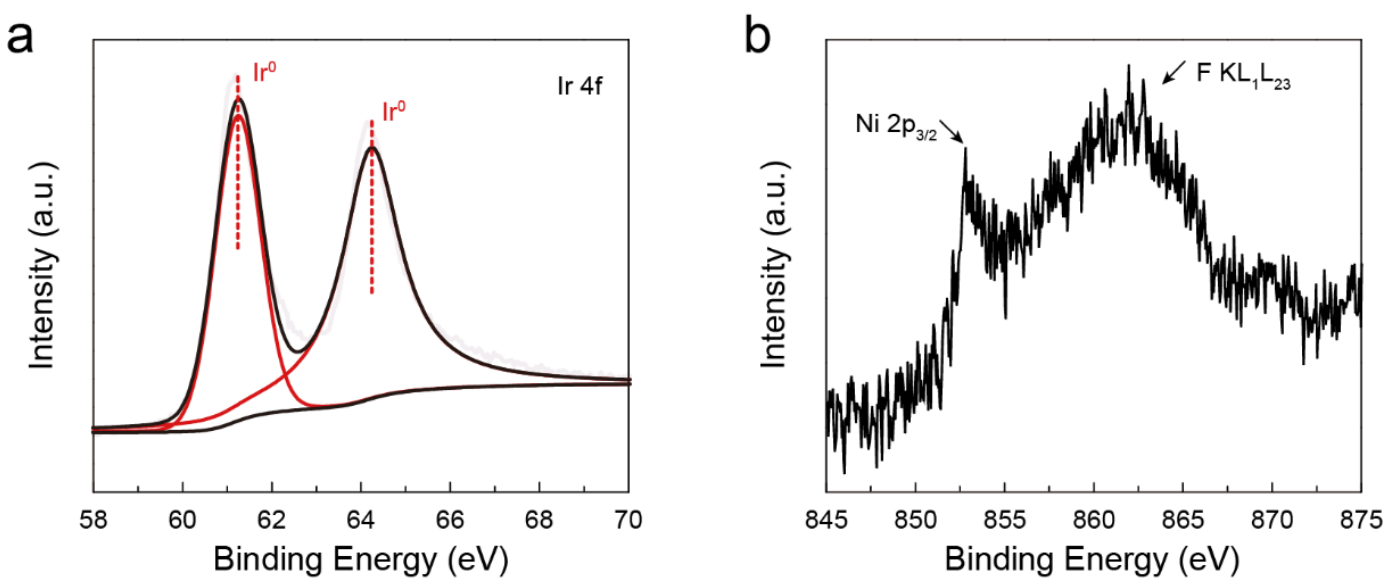

Figure S10. The XPS spectra of the Ni/np-Ir at Ir $4 f$ region (a) and Ni $2 p$ region (b). In Ir $4 f$ region, the $4 f_{7 / 2}$ and $4 f_{5 / 2}$ peaks located at $61.23 \mathrm{eV}$ and $64.23 \mathrm{eV}$, respectively, indicating the metallic nature of Ir in Ni/np-Ir. ${ }^{2}$ Note that it is difficult to determine the state of the atomic Ni species by XPS due to the low content of Ni species and the overlapping of $\mathrm{F} \mathrm{KL}_{1} \mathrm{~L}_{23}$ signals. The $\mathrm{F}$ species comes from the Nafion solution. ${ }^{3}$ 

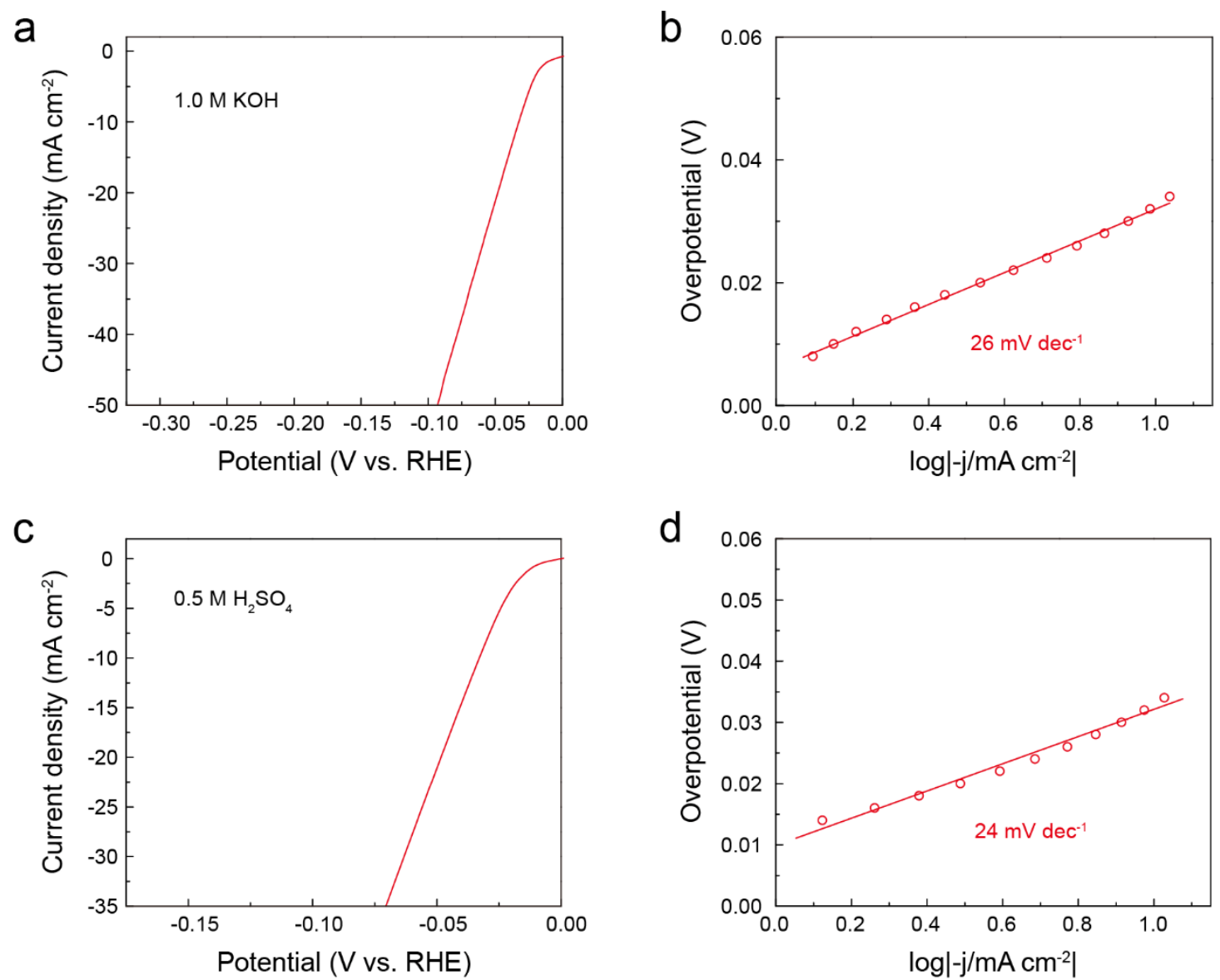

Figure S11. Electrocatalytic HER performance of Ni/np-Ir. (a) Polarization curves (without iR-correction) and (b) corresponding Tafel slopes of Ni/np-Ir tested in $1.0 \mathrm{M}$ KOH solutions. (c) Polarization curves (without iR-correction) and (d) corresponding Tafel slopes of $\mathrm{Ni} / \mathrm{np}$-Ir tested in $0.5 \mathrm{M} \mathrm{H}_{2} \mathrm{SO}_{4}$ solutions. 

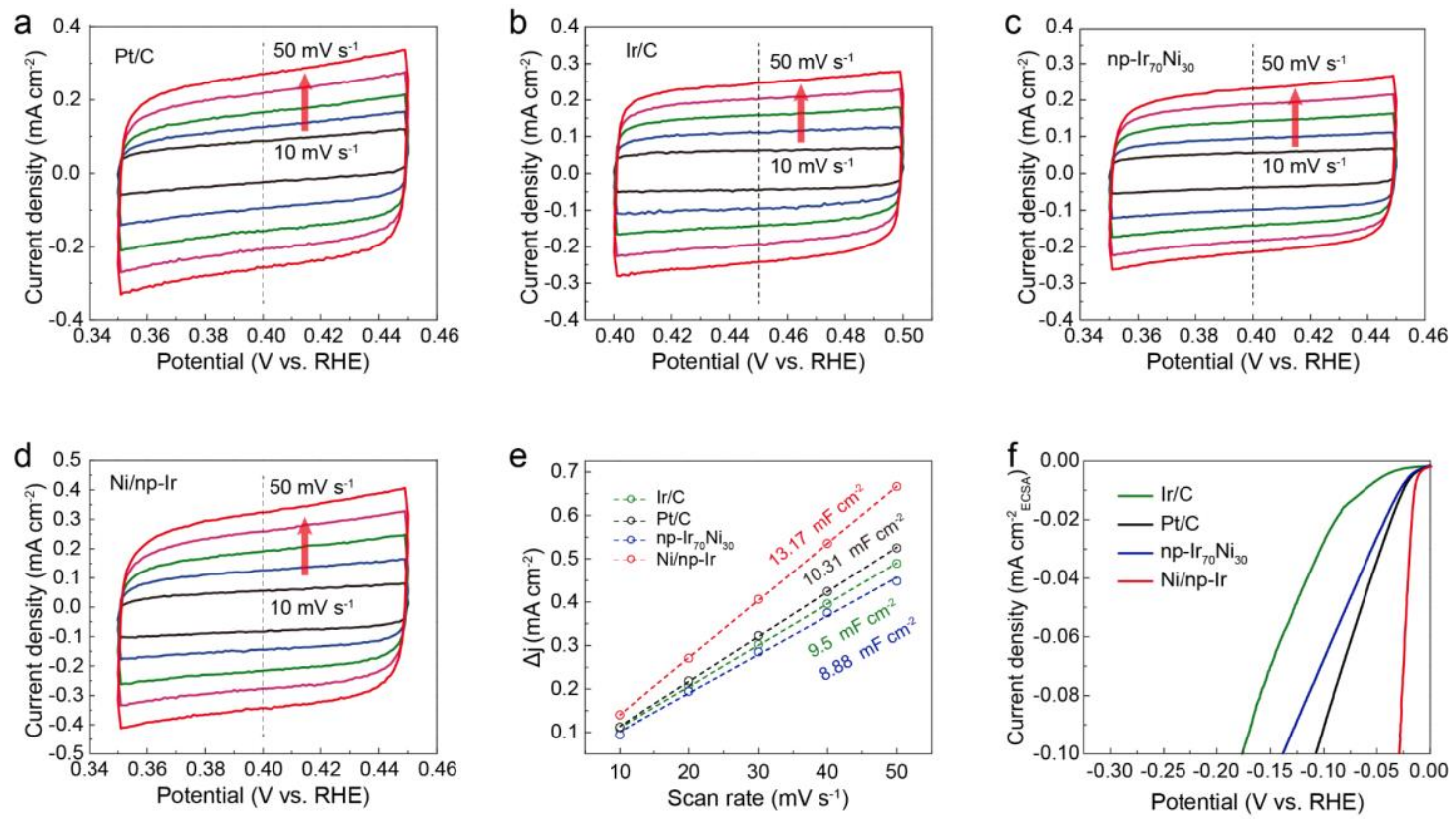

Figure S12. ECSA characterizations. (a-d) CV curves of $\mathrm{Pt} / \mathrm{C}, \mathrm{Ir} / \mathrm{C}, \mathrm{np}-\mathrm{Ir}_{70} \mathrm{Ni}_{30}$, and

$\mathrm{Ni} / \mathrm{np}$-Ir in 1.0 M KOH. The scan rate of CV measurement was set to step from 10 to $50 \mathrm{mV} \mathrm{s}^{-1}$. (e) Corresponding $C_{\mathrm{dl}}$ measurements of different samples. (f) The polarization curves of $\mathrm{Ni} / \mathrm{np}-\mathrm{Ir}, \mathrm{np}-\mathrm{Ir}_{70} \mathrm{Ni}_{30}, \mathrm{Pt} / \mathrm{C}$, and $\mathrm{Ir} / \mathrm{C}$ normalized by the ECSA. 

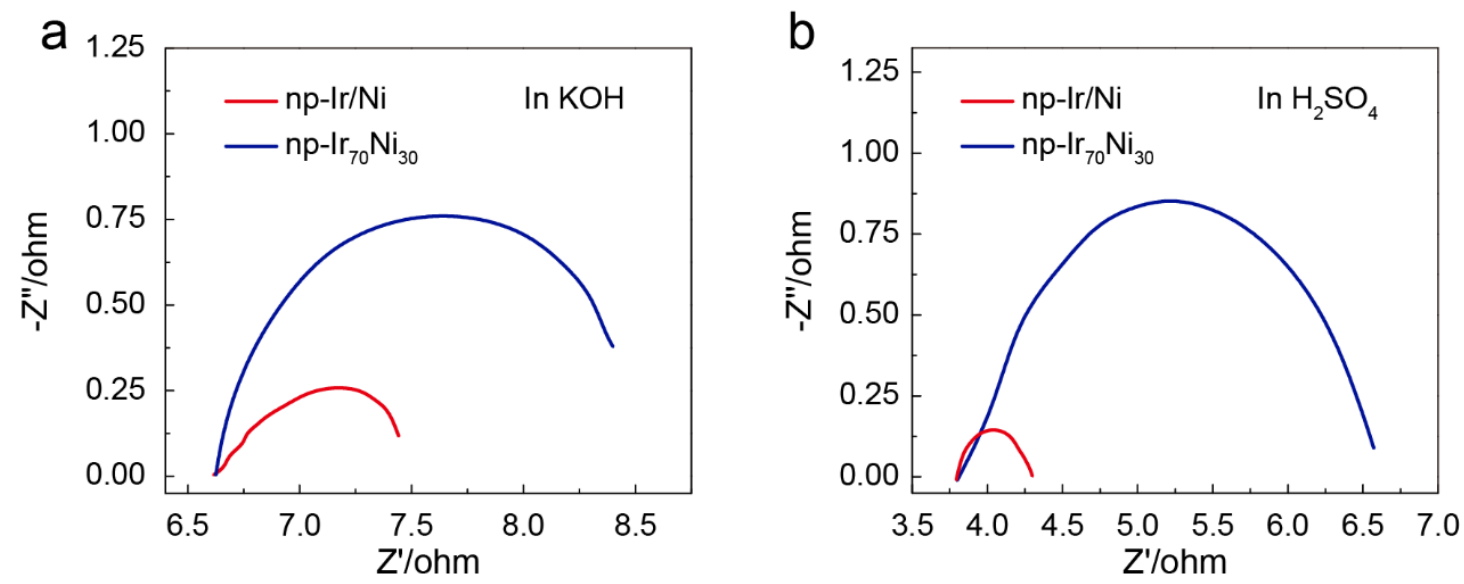

Figure S13. Electrochemical impedance spectroscopy of Ni/np-Ir and np- $\operatorname{Ir}_{70} \mathrm{Ni}_{30}$ in 1.0 $\mathrm{M} \mathrm{KOH} \mathrm{(a)} \mathrm{and} 0.5 \mathrm{M} \mathrm{H}_{2} \mathrm{SO}_{4}(\mathrm{~b})$.

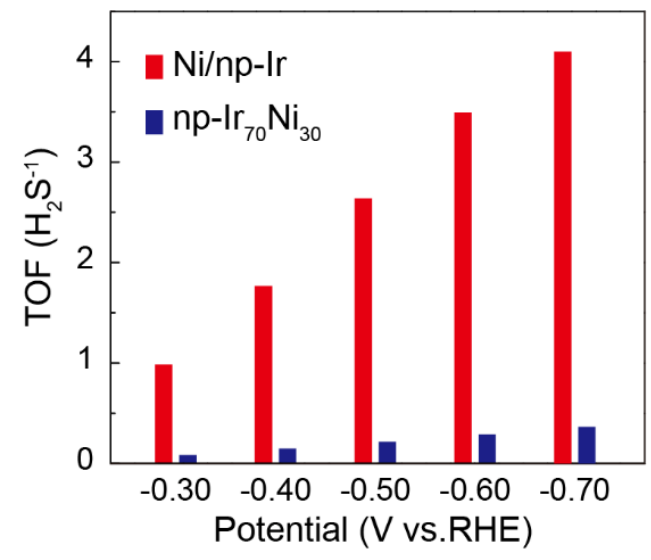

Figure S14. TOF values of Ni/np-Ir (red bars) and $\mathrm{np}-\mathrm{Ir}_{70} \mathrm{Ni}_{30}$ (blue bars) at different potentials. 

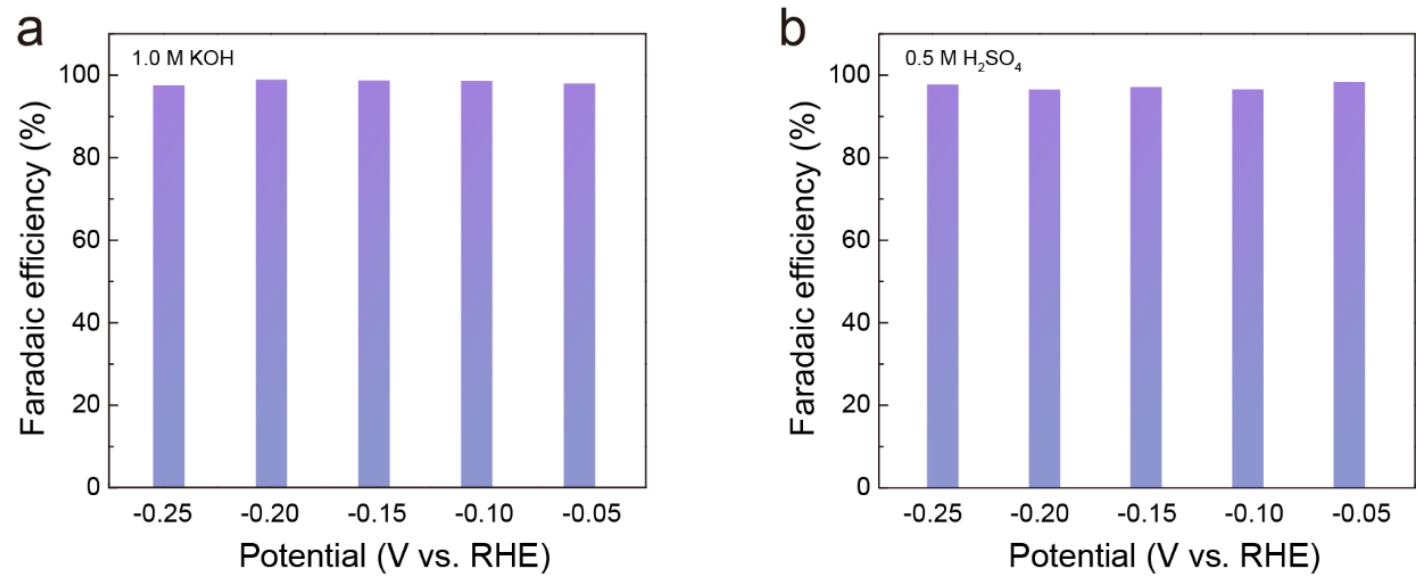

Figure S15. Faradaic efficiency of Ni/np-Ir under different applied potentials in $1.0 \mathrm{M}$ $\mathrm{KOH}(\mathrm{a})$ and $0.5 \mathrm{M} \mathrm{H}_{2} \mathrm{SO}_{4}(\mathrm{~b})$.
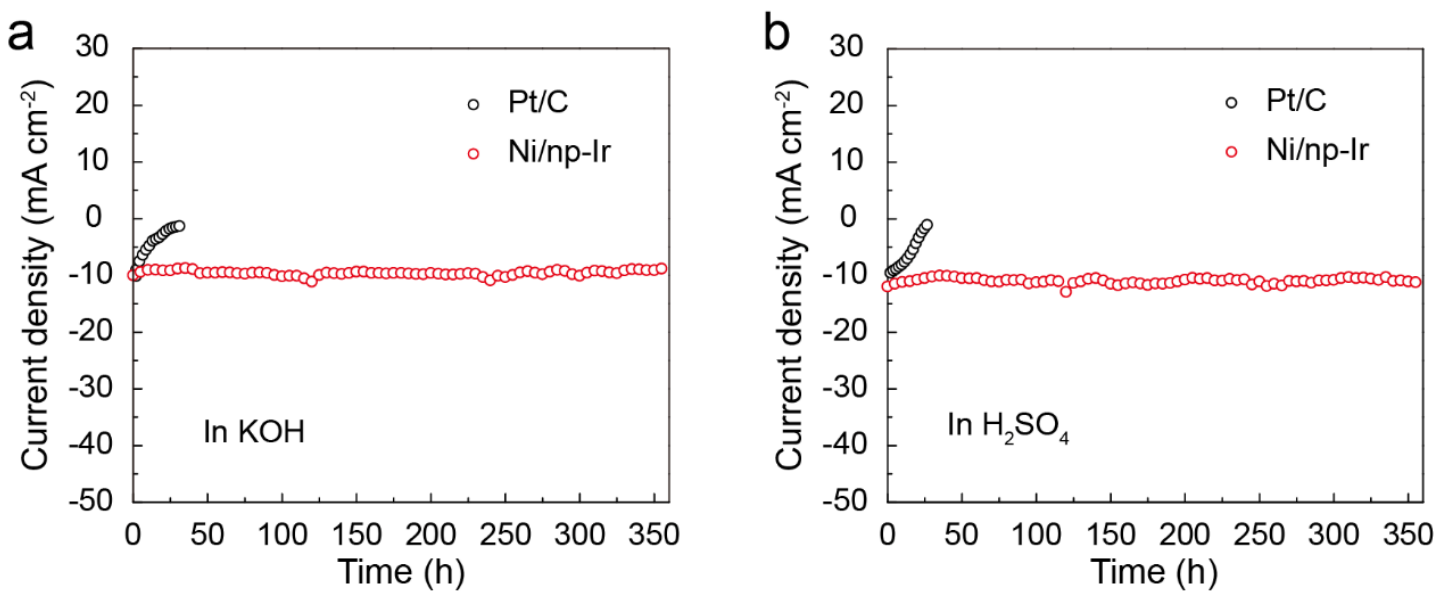

Figure S16. (a) Chronoamperometry curves of Ni/np-Ir (at an overpotential of $20 \mathrm{mV}$ ) and $\mathrm{Pt} / \mathrm{C}$ (at an overpotential of $40 \mathrm{mV}$ ) in $1.0 \mathrm{M} \mathrm{KOH}$. (b) Chronoamperometry curves of $\mathrm{Ni} / \mathrm{np}-\mathrm{Ir}$ (at an overpotential of $17 \mathrm{mV}$ ) and $\mathrm{Pt} / \mathrm{C}$ (at an overpotential of $30 \mathrm{mV}$ ) in $0.5 \mathrm{M} \mathrm{H}_{2} \mathrm{SO}_{4}$. 

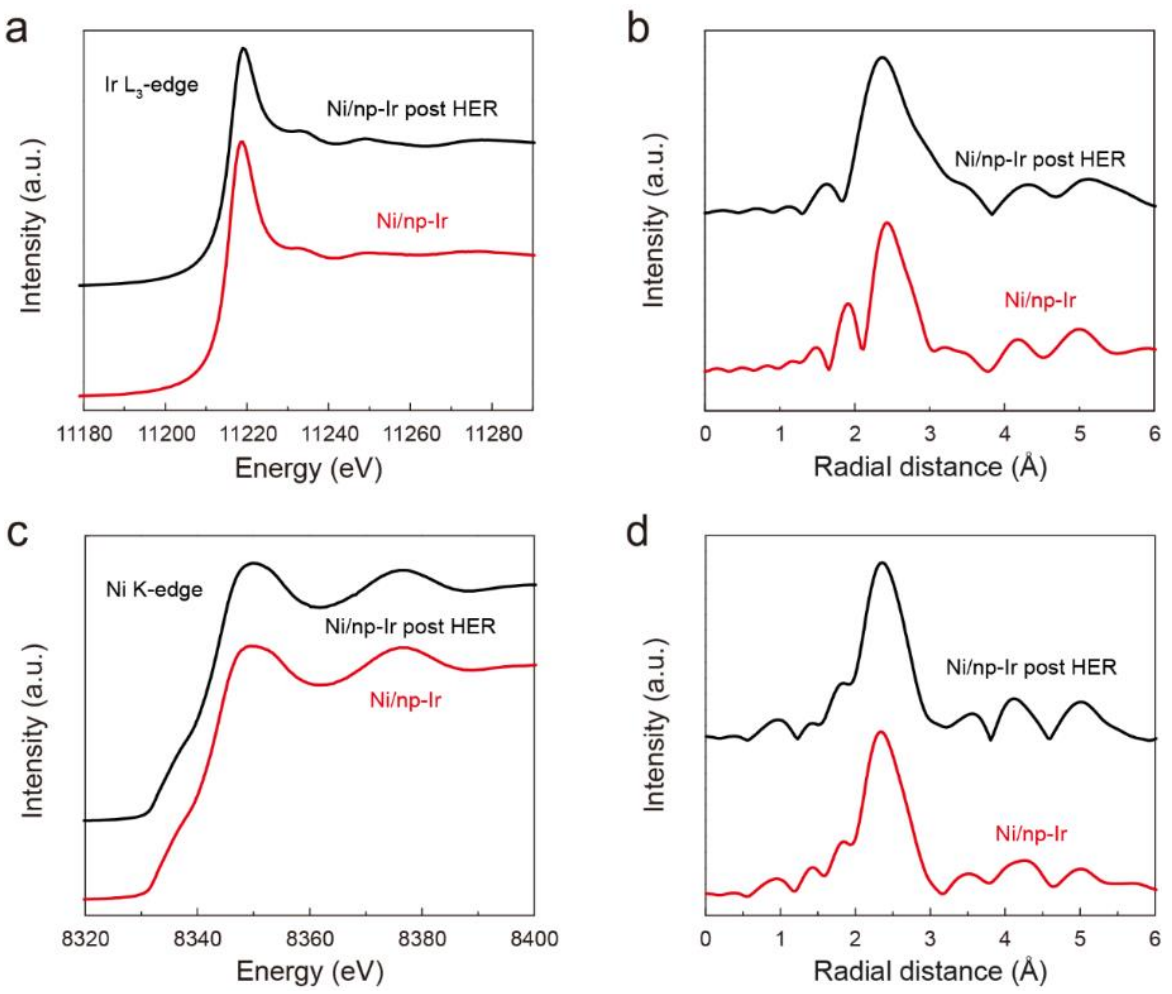

Figure S17. The XAS characterizations of Ni/np-Ir before and after long-time

HER operation. (a, c) XANES spectra at Ir L L $_{3}$ - and Ni K-edge. (b, d) Corresponding FT-EXAFS spectra. 

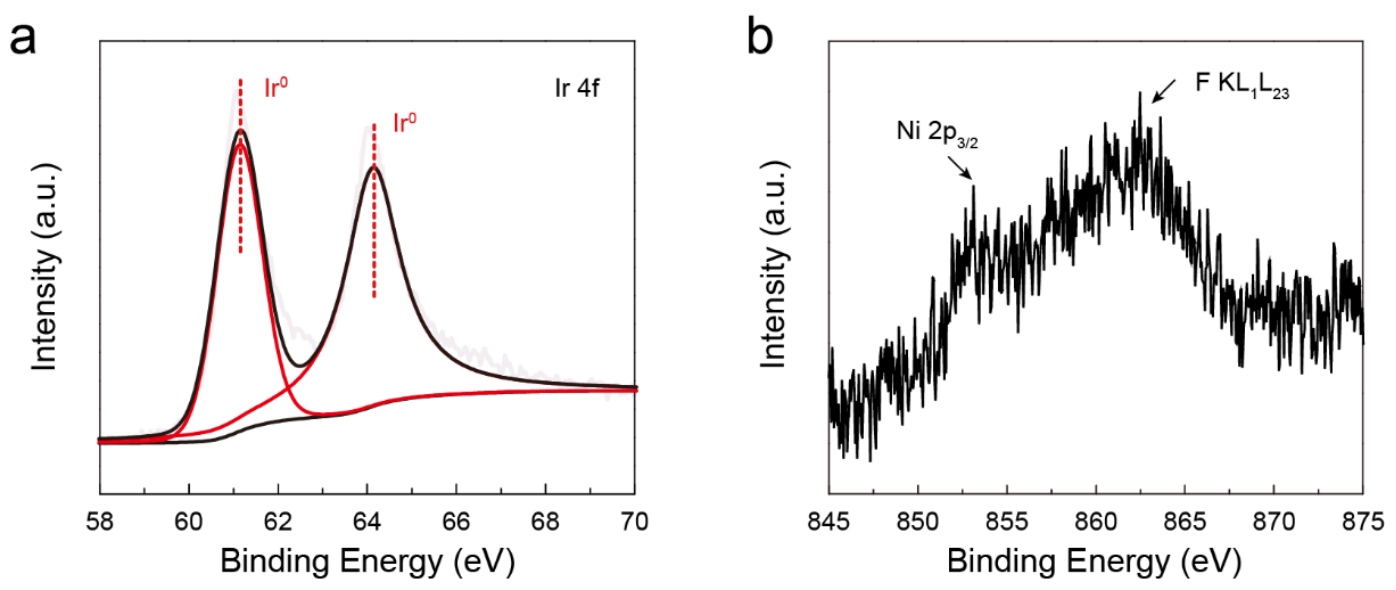

Figure S18. The XPS spectra of the Ni/np-Ir after long-time HER operation. (a) Ir $4 f$ region. (b) Ni $2 p$ region.

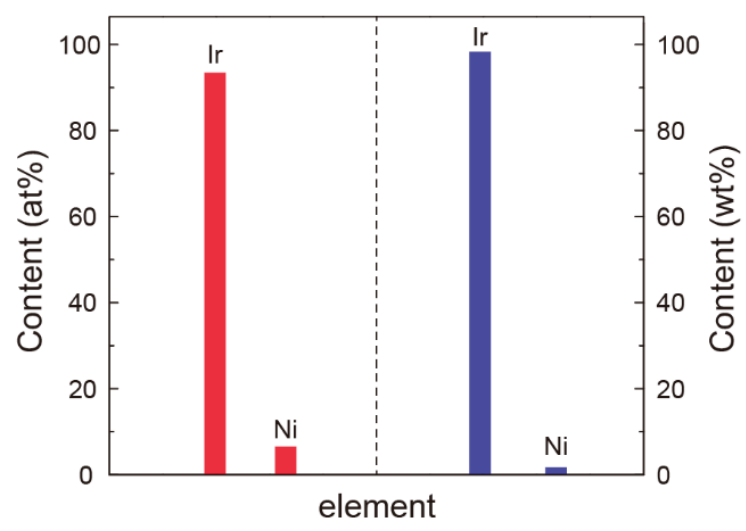

Figure S19. The ICP-OES analyses of Ni/np-Ir. The red bars on the left represent the atomic content of $\mathrm{Ir}$ and $\mathrm{Ni}$ element in $\mathrm{Ni} / \mathrm{np}$-Ir, while the blue bars on the right represent the weight content of $\mathrm{Ir}$ and $\mathrm{Ni}$ element in Ni/np-Ir. 

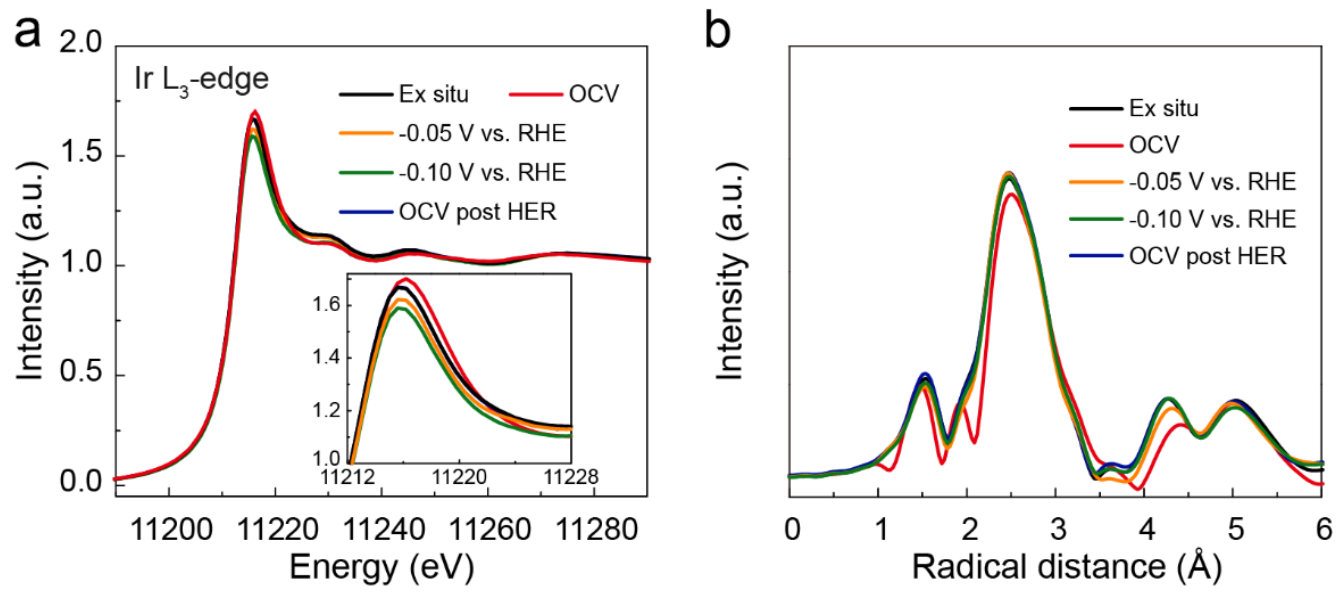

Figure S20. Operando XAS characterizations for Ni/np-Ir. (a) The Ir $\mathrm{L}_{3}$-edge XANES spectra of $\mathrm{Ni} / \mathrm{np}$-Ir obtained under different applied voltages in $1.0 \mathrm{M} \mathrm{KOH}$. Inset shows the magnified white line region. (b) The corresponding FT-EXAFS spectra from (a). 
a

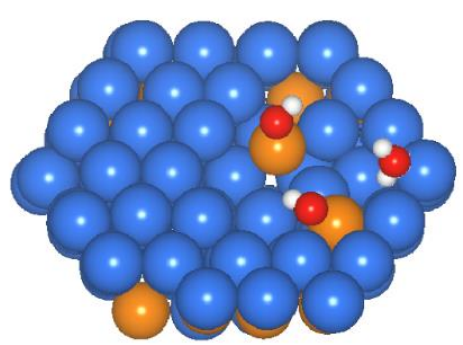

b

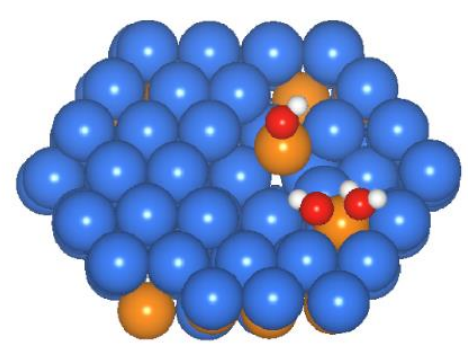

Figure S21. The adsorption of $\mathrm{H}_{2} \mathrm{O}$ molecule on $\mathrm{Ir}$ (a) and $\mathrm{Ni}$ (b) sites of Ni/np-Ir, respectively.

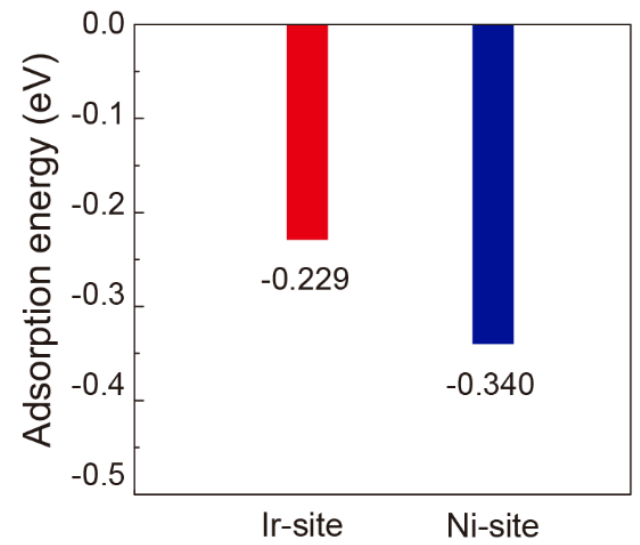

Figure S22. Comparison of the adsorption energy of water on Ir and Ni sites of Ni/npIr. 


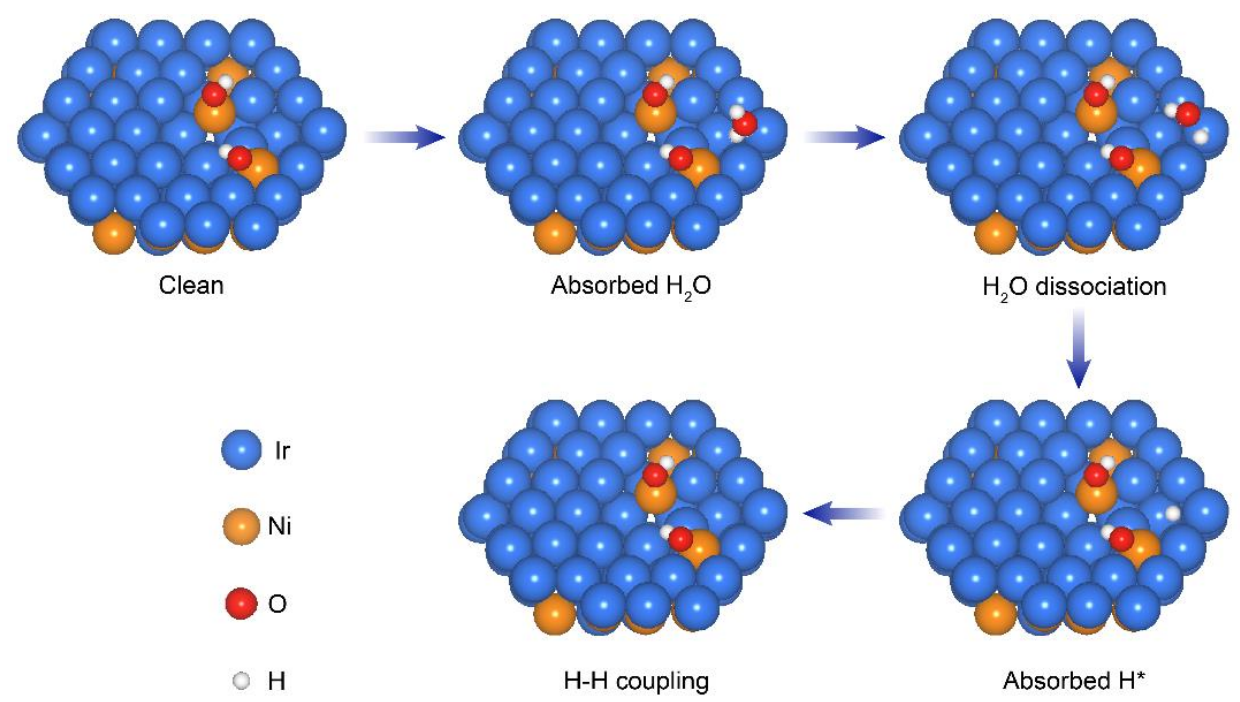

Figure S23. Schematic of the Volmer step and H-H coupling step at Ir site on Ni/np-Ir surface.
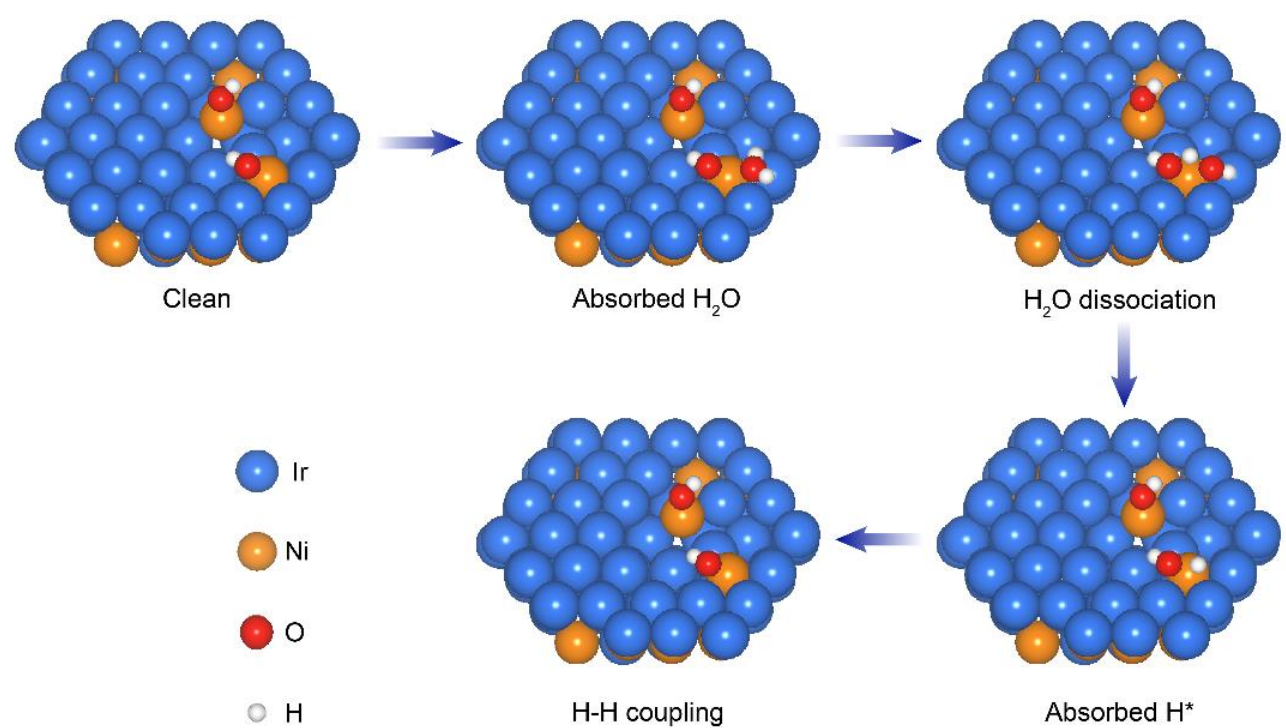

$\mathrm{H}-\mathrm{H}$ coupling

Absorbed $\mathrm{H}^{\star}$

Figure S24. Schematic of the Volmer step and H-H coupling step at Ni site on Ni/np-Ir surface. 
Table S1. Structural parameter extracted from the Ni K-edge EXAFS fitting. (CN: coordination number; $\sigma^{2}$ : Debye-Waller factor).

\begin{tabular}{cccccc}
\hline Sample & Scattering pair & $\mathrm{R}(\AA)$ & $\mathrm{CN}$ & $\Delta \mathrm{E}_{0}(\mathrm{eV})$ & $\sigma^{2}\left(10^{-3} \AA^{2}\right)$ \\
\hline Ni foil & Ni-Ni & 2.49 & 12.0 & 6.1 & 5.9 \\
& $\mathrm{Ni}-\mathrm{Ni}$ & 2.51 & 3.5 & 5.6 & 9.1 \\
np-Ir70Ni30 & $\mathrm{Ir}-\mathrm{Ni}$ & 2.59 & 3.2 & 11.9 & 6.4 \\
& $\mathrm{Ir}-\mathrm{Ni}$ & 2.61 & 7.9 & 11.52 & 7.8 \\
Ni/np-Ir & & & & & \\
\hline
\end{tabular}

Table S2. Comparison of the price for different noble metals. ${ }^{1}$

\begin{tabular}{cccc}
\hline Metal & symbol & Unit of Measure & U.S. \\
\hline Platinum & $\mathrm{Pt}$ & troy ounce & $\$ 974.00$ \\
Iridium & $\mathrm{Ir}$ & troy ounce & $\$ 990.00$ \\
\hline
\end{tabular}

Table S3. Comparison of the catalytic HER performance of catalysts in $1.0 \mathrm{M} \mathrm{KOH}$ electrolyte $\left(\eta_{10}\right.$ : overpotential at $10 \mathrm{~mA} \mathrm{~cm}^{-2}, j$ : current density).

\begin{tabular}{|c|c|c|c|c|c|c|}
\hline Materials & $\begin{array}{c}\text { Mass } \\
\text { Loading }\end{array}$ & Electrolyte & $\begin{array}{c}\eta_{10} \\
(\mathrm{mV})\end{array}$ & $\begin{array}{l}\text { Tafel slope } \\
\left(\mathrm{mV} \text { dec }^{-1}\right)\end{array}$ & $\begin{array}{c}\text { stability } \\
\text { test (h) }\end{array}$ & Ref. \\
\hline$n p-\operatorname{Ir}_{70} \mathrm{Ni}_{30}$ & $\begin{array}{c}20.24 \mathrm{ug}_{\mathrm{II}} \\
\mathrm{cm}^{-2}\end{array}$ & $1.0 \mathrm{M} \mathrm{KOH}$ & 51.2 & 51 & NA & $\begin{array}{l}\text { This } \\
\text { work }\end{array}$ \\
\hline 100 th & NA & $1.0 \mathrm{M} \mathrm{KOH}$ & 34.9 & NA & NA & $\begin{array}{l}\text { This } \\
\text { work }\end{array}$ \\
\hline 300 th & NA & $1.0 \mathrm{M} \mathrm{KOH}$ & 23.2 & NA & NA & $\begin{array}{l}\text { This } \\
\text { work }\end{array}$ \\
\hline Ni/np-Ir & $\begin{array}{c}22.09 \mathrm{ug}_{\mathrm{Ir}} \\
\mathrm{cm}^{-2}\end{array}$ & $1.0 \mathrm{M} \mathrm{KOH}$ & 20 & 26 & $\begin{array}{c}360 \\
(j=10 \mathrm{~mA} \\
\left.\mathrm{cm}^{-2}\right)\end{array}$ & $\begin{array}{l}\text { This } \\
\text { work }\end{array}$ \\
\hline Pt-Ni ASs & $\begin{array}{c}0.017 \mathrm{mg} \\
\mathrm{cm}^{-2}\end{array}$ & $1.0 \mathrm{M} \mathrm{KOH}$ & 27.7 & 27 & NA & 4 \\
\hline $\begin{array}{c}\operatorname{IrCo} @ N C- \\
500\end{array}$ & $\begin{array}{c}0.285 \mathrm{mg} \\
\mathrm{cm}^{-2}\end{array}$ & $1.0 \mathrm{M} \mathrm{KOH}$ & 45 & 80 & NA & 5 \\
\hline $\begin{array}{c}\text { IrNi@OC- } \\
430\end{array}$ & $\begin{array}{c}0.285 \mathrm{mg} \\
\mathrm{cm}^{-2}\end{array}$ & $1.0 \mathrm{M} \mathrm{KOH}$ & 27 & 50 & $\begin{array}{c}\sim 10 \\
(j=10 \mathrm{~mA} \\
\left.\mathrm{cm}^{-2}\right)\end{array}$ & 6 \\
\hline
\end{tabular}




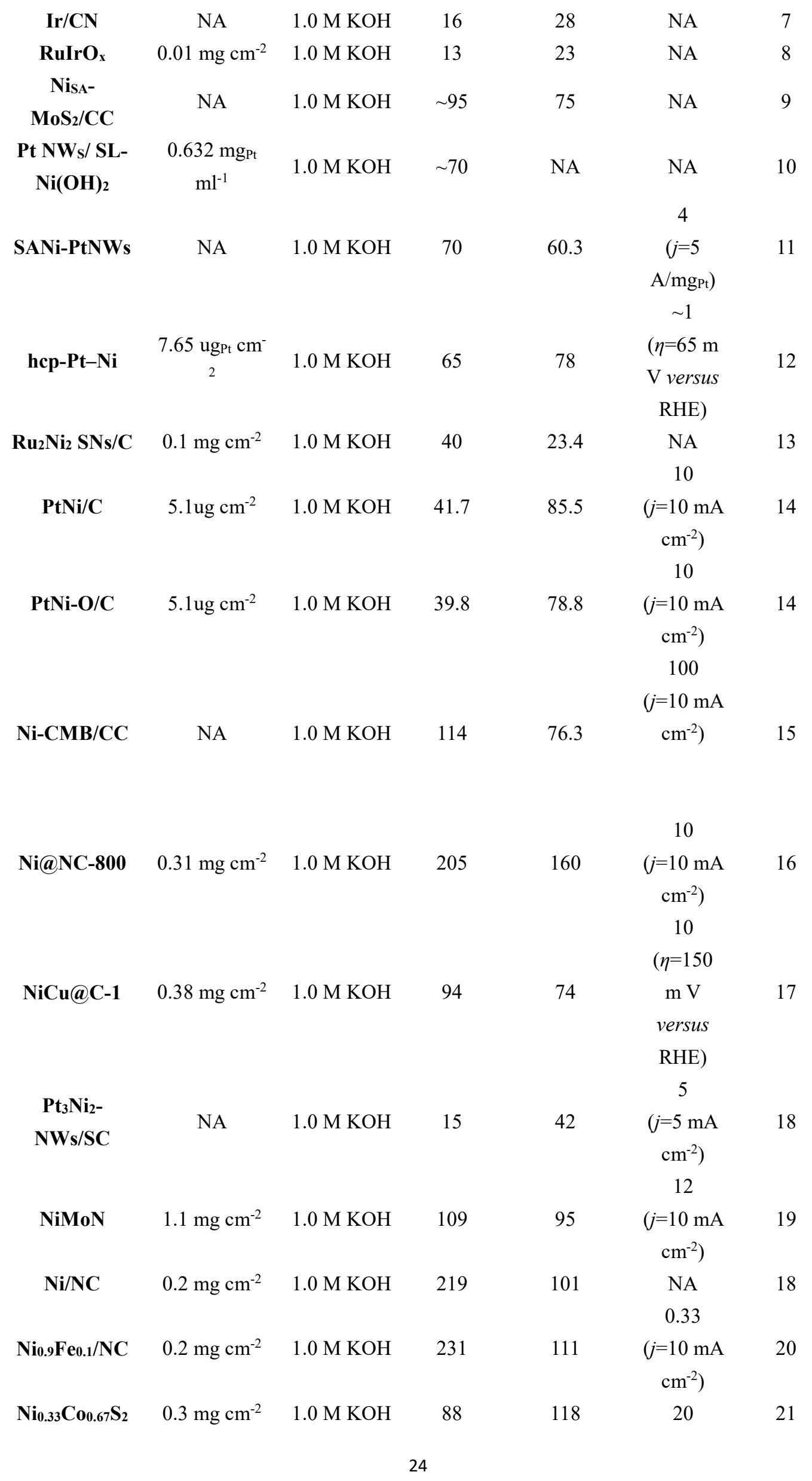




\begin{tabular}{|c|c|c|c|c|c|c|}
\hline nanowire & & & & \multicolumn{2}{|c|}{$(\eta=-100$} & \\
\hline $\mathrm{Ni}_{\mathrm{C}}-\mathrm{MoS}_{2} / \mathrm{CC}$ & NA & $1.0 \mathrm{M} \mathrm{KOH}$ & 103 & 157 & NA & 9 \\
\hline
\end{tabular}

NA: not available

Table S4. Comparison of the catalytic HER performance of catalysts in $0.5 \mathrm{M} \mathrm{H}_{2} \mathrm{SO}_{4}$ electrolyte.

\begin{tabular}{|c|c|c|c|c|c|c|}
\hline Materials & $\begin{array}{c}\text { Mass } \\
\text { loading }\end{array}$ & Electrolyte & $\begin{array}{c}\eta_{10} \\
(\mathrm{mV})\end{array}$ & $\begin{array}{l}\text { Tafel slope } \\
\left(\mathrm{mV} \operatorname{dec}^{-1}\right)\end{array}$ & $\begin{array}{c}\text { stability } \\
\text { test (h) }\end{array}$ & Ref. \\
\hline$n p-I r_{70} \mathrm{Ni}_{30}$ & $\begin{array}{c}20.24 \mathrm{ug}_{\mathrm{Ir}} \\
\mathrm{cm}^{-2}\end{array}$ & $0.5 \mathrm{M} \mathrm{H}_{2} \mathrm{SO}_{4}$ & 35.2 & 43 & NA & $\begin{array}{l}\text { This } \\
\text { work }\end{array}$ \\
\hline Ni/np-Ir & $\begin{array}{c}22.09 \mathrm{ug}_{\mathrm{Ir}} \\
\mathrm{cm}^{-2}\end{array}$ & $0.5 \mathrm{M} \mathrm{H}_{2} \mathrm{SO}_{4}$ & 17.1 & 24 & $\begin{array}{c}360 \\
(j=10 \mathrm{~mA} \\
\left.\mathrm{cm}^{-2}\right)\end{array}$ & $\begin{array}{l}\text { This } \\
\text { work }\end{array}$ \\
\hline $\begin{array}{c}\text { IrCo@NC- } \\
500\end{array}$ & $\begin{array}{c}0.285 \mathrm{mg} \\
\mathrm{cm}^{-2}\end{array}$ & $0.5 \mathrm{M} \mathrm{H}_{2} \mathrm{SO}_{4}$ & 23 & 80 & 1.38 & 5 \\
\hline $\begin{array}{c}\mathrm{IrCo} @ \mathrm{NC}- \\
\mathbf{8 0 0}\end{array}$ & $\begin{array}{c}0.285 \mathrm{mg} \\
\mathrm{cm}^{-2}\end{array}$ & $0.5 \mathrm{M} \mathrm{H}_{2} \mathrm{SO}_{4}$ & 52 & 74 & NA & 5 \\
\hline $\begin{array}{c}\text { IrNi@OC- } \\
\quad 430\end{array}$ & $\begin{array}{c}0.285 \mathrm{mg} \\
\mathrm{cm}^{-2}\end{array}$ & $0.5 \mathrm{M} \mathrm{H}_{2} \mathrm{SO}_{4}$ & 35 & 18 & $\begin{array}{c}\sim 11.11 \\
(j=100 \mathrm{~mA} \\
\left.\mathrm{cm}^{-2}\right)\end{array}$ & 6 \\
\hline $\mathrm{NiCu} @ \mathrm{C}-1$ & $0.38 \mathrm{mg} \mathrm{cm}^{-2}$ & $0.5 \mathrm{M} \mathrm{H}_{2} \mathrm{SO}_{4}$ & 48 & 63 & NA & 17 \\
\hline $\operatorname{RuIrO}_{\mathbf{x}}$ & $0.01 \mathrm{mg} \mathrm{cm}^{-2}$ & $0.5 \mathrm{M} \mathrm{H}_{2} \mathrm{SO}_{4}$ & 12 & 21 & NA & 8 \\
\hline $\begin{array}{l}\mathrm{Ni}_{0.33} \mathrm{Co} \mathrm{Co.67}_{67} \mathrm{~S} \\
2 \text { nanowire }\end{array}$ & $0.3 \mathrm{mg} \mathrm{cm}^{-2}$ & $0.5 \mathrm{M} \mathrm{H}_{2} \mathrm{SO}_{4}$ & 73 & 44.1 & $\begin{array}{c}5 \\
(\eta=-80 \\
\mathrm{mV})\end{array}$ & 21 \\
\hline IrNi NCs & $\begin{array}{c}10.0 \mathrm{ug}_{\mathrm{Ir}} \mathrm{cm}^{-} \\
2\end{array}$ & $0.1 \mathrm{M} \mathrm{HClO}_{4}$ & 34.3 & 19 & NA & 22 \\
\hline IrCo-PHNC & $\begin{array}{c}10.0 \mathrm{ug}_{\mathrm{Ir}} \mathrm{cm}^{-} \\
2\end{array}$ & $0.1 \mathrm{M} \mathrm{HClO}_{4}$ & 26.6 & 21 & $\begin{array}{c}1 \\
(j=5 \mathrm{~mA} \\
\left.\mathrm{cm}^{-2}\right)\end{array}$ & 22 \\
\hline IrNiFe NPs & NA & $0.5 \mathrm{M} \mathrm{HClO}_{4}$ & NA & 24 & $\begin{array}{c}\sim 5.5 \\
(j=10 \mathrm{~mA} \\
\left.\mathrm{cm}^{-2}\right)\end{array}$ & 23 \\
\hline IrNi NCs & NA & $0.5 \mathrm{M} \mathrm{H}_{2} \mathrm{SO}_{4}$ & 32 & NA & NA & 24 \\
\hline $\begin{array}{c}\text { Ni-doped } \\
\mathrm{RuO}_{2} \mathrm{NW}_{\mathrm{s}}\end{array}$ & NA & $0.5 \mathrm{M} \mathrm{H}_{2} \mathrm{SO}_{4}$ & 135 & 78 & NA & 25 \\
\hline $\mathrm{IrO}_{2}-\mathrm{TiO}_{2}$ & NA & $0.5 \mathrm{M} \mathrm{H}_{2} \mathrm{SO}_{4}$ & 46.8 & 107 & NA & 26 \\
\hline
\end{tabular}

NA: not available 


\section{References}

(1) Zhu, Y.; Tahini, H. A.; Hu, Z.; Dai, J.; Chen, Y.; Sun, H.; Zhou, W.; Liu, M.; Smith, S. C.; Wang, H.; Shao, Z. Unusual Synergistic Effect in Layered Ruddlesden-Popper Oxide Enables Ultrafast Hydrogen Evolution. Nat. Commun. 2019, 10, 149.

(2) Zhang, Y.; Wu, C.; Jiang, H.; Lin, Y.; Liu, H.; He, Q.; Chen, S.; Duan, T.; Song, L. Atomic Iridium Incorporated in Cobalt Hydroxide for Efficient Oxygen Evolution Catalysis in Neutral Electrolyte. Adv. Mater. 2018, 30, 1707522.

(3) Fan, L.; Liu, P. F.; Yan, X.; Gu, L.; Yang, Z. Z.; Yang, H. G.; Qiu, S.; Yao, X. Atomically Isolated Nickel Species Anchored on Graphitized Carbon for Efficient Hydrogen Evolution Electrocatalysis. Nat. Commun. 2016, 7, 10667.

(4) Zhang, Z.; Liu, G.; Cui, X.; Chen, B.; Zhu, Y.; Gong, Y.; Saleem, F.; Xi, S.; Du, Y.; Borgna, A.; Lai, Z.; Zhang, Q.; Li, B.; Zong, Y.; Han, Y.; Gu, L.; Zhang, H. Crystal Phase and Architecture Engineering of Lotus-Thalamus-Shaped Pt-Ni Anisotropic Superstructures for Highly Efficient Electrochemical Hydrogen Evolution. Adv. Mater. 2018, 30, 1801741.

(5) Jiang, P.; Chen, J.; Wang, C.; Yang, K.; Gong, S.; Liu, S.; Lin, Z.; Li, M.; Xia, G.; Yang, Y.; Su, J.; Chen, Q. Tuning the Activity of Carbon for Electrocatalytic Hydrogen Evolution via an Iridium-Cobalt Alloy Core Encapsulated in Nitrogen-Doped Carbon Cages. Adv. Mater. 2018, 30, 1705324.

(6) Gong, S.; Wang, C.; Jiang, P.; Yang, K.; Lu, J.; Huang, M.; Chen, S.; Wang, J.; Chen, Q. O Species-Decorated Graphene Shell Encapsulating Iridium-Nickel Alloy as an Efficient Electrocatalyst towards Hydrogen Evolution Reaction. J. Mater. Chem. A 
2019, 7, 15079-15088.

(7) Wang, H.; Ming, M.; Hu, M.; Xu, C.; Wang, Y.; Zhang, Y.; Gao, D.; Bi, J.; Fan, G.;

Hu, J. S. Size and Electronic Modulation of Iridium Nanoparticles on NitrogenFunctionalized Carbon toward Advanced Electrocatalysts for Alkaline Water Splitting. ACS Appl. Mater. Interfaces 2018, 10, 22340-22347.

(8) Zhuang, Z.; Wang, Y.; Xu, C. Q.; Liu, S.; Chen, C.; Peng, Q.; Zhuang, Z.; Xiao, H.; Pan, Y.; Lu, S.; Yu, R.; Cheong, W. C.; Cao, X.; Wu, K.; Sun, K.; Wang, Y.; Wang, D.; Li, J.; Li, Y. Three-Dimensional Open Nano-Netcage Electrocatalysts for Efficient PhUniversal Overall Water Splitting. Nat. Commun. 2019, 10, 4875.

(9) Wang, Q.; Zhao, Z. L.; Dong, S.; He, D.; Lawrence, M. J.; Han, S.; Cai, C.; Xiang, S.; Rodriguez, P.; Xiang, B.; Wang, Z.; Liang, Y.; Gu, M. Design of Active Nickel Single-Atom Decorated $\mathrm{MoS}_{2}$ as a $\mathrm{pH}-$ Universal Catalyst for Hydrogen Evolution Reaction. Nano Energy 2018, 53, 458-467.

(10) Yin, H.; Zhao, S.; Zhao, K.; Muqsit, A.; Tang, H.; Chang, L.; Zhao, H.; Gao, Y.; Tang, Z. Ultrathin Platinum Nanowires Grown on Single-Layered Nickel Hydroxide with High Hydrogen Evolution Activity. Nat. Commun. 2015, 6, 6430.

(11) Li, M.; Duanmu, K.; Wan, C.; Cheng, T.; Zhang, L.; Dai, S.; Chen, W.; Zhao, Z.; Li, P.; Fei, H.; Zhu, Y.; Yu, R.; Luo, J.; Zang, K.; Lin, Z.; Ding, M.; Huang, J.; Sun, H.; Guo, J.; Pan, X.; et al. Single-Atom Tailoring of Platinum Nanocatalysts for HighPerformance Multifunctional Electrocatalysis. Nat. Catal. 2019, 2, 495-503.

(12) Cao, Z.; Chen, Q.; Zhang, J.; Li, H.; Jiang, Y.; Shen, S.; Fu, G.; Lu, B. A.; Xie, Z.; Zheng, L. Platinum-Nickel Alloy Excavated Nano-Multipods with Hexagonal Close- 
Packed Structure and Superior Activity towards Hydrogen Evolution Reaction. Nat. Commun. 2017, 8, 15131.

(13) Ding, J.; Shao, Q.; Feng, Y.; Huang, X. Ruthenium-Nickel Sandwiched Nanoplates for Efficient Water Splitting Electrocatalysis. Nano Energy 2018, 47, 1-7.

(14) Zhao, Z.; Liu, H.; Gao, W.; Xue, W.; Liu, Z.; Huang, J.; Pan, X.; Huang, Y. SurfaceEngineered PtNi-O Nanostructure with Record-High Performance for Electrocatalytic Hydrogen Evolution Reaction. J. Am. Chem. Soc. 2018, 140, 9046-9050.

(15) Dutta, S.; Han, H.; Je, M.; Choi, H.; Kwon, J.; Park, K.; Indra, A.; Kim, K. M.; Paik, U.; Song, T. Chemical and Structural Engineering of Transition Metal Boride towards Excellent and Sustainable Hydrogen Evolution Reaction. Nano Energy 2020, $67,104245$.

(16) Xu, Y.; Tu, W.; Zhang, B.; Yin, S.; Huang, Y.; Kraft, M.; Xu, R. Nickel Nanoparticles Encapsulated in Few-Layer Nitrogen-Doped Graphene Derived from Metal-Organic Frameworks as Efficient Bifunctional Electrocatalysts for Overall Water Splitting. Adv. Mater. 2017, 29, 1605957.

(17) Shen, Y.; Zhou, Y.; Wang, D.; Wu, X.; Li, J.; Xi, J. Nickel-Copper Alloy Encapsulated in Graphitic Carbon Shells as Electrocatalysts for Hydrogen Evolution Reaction. Adv. Energy Mater. 2018, 8, 1701759.

(18) Wang, P.; Zhang, X.; Zhang, J.; Wan, S.; Guo, S.; Lu, G.; Yao, J.; Huang, X. Precise Tuning in Platinum-Nickel/Nickel Sulfide Interface Nanowires for Synergistic Hydrogen Evolution Catalysis. Nat. Commun. 2017, 8, 14580.

(19) Zhang, Y.; Ouyang, B.; Xu, J.; Chen, S.; Rawat, R. S.; Fan, H. J. 3D Porous 
Hierarchical Nickel-Molybdenum Nitrides Synthesized by RF Plasma as Highly Active and Stable Hydrogen-Evolution-Reaction Electrocatalysts. Adv. Energy Mater. 2016, 6, 1600221.

(20) Zhang, X.; Xu, H.; Li, X.; Li, Y.; Yang, T.; Liang, Y. Facile Synthesis of NickelIron/Nanocarbon Hybrids as Advanced Electrocatalysts for Efficient Water Splitting. ACS Catal. 2015, 6, 580-588.

(21) Peng, Z.; Jia, D.; Al-Enizi, A. M.; Elzatahry, A. A.; Zheng, G. From Water Oxidation to Reduction: Homologous Ni-Co Based Nanowires as Complementary Water Splitting Electrocatalysts. Adv. Energy Mater. 2015, 5, 1402031.

(22) Feng, J.; Lv, F.; Zhang, W.; Li, P.; Wang, K.; Yang, C.; Wang, B.; Yang, Y.; Zhou, J.; Lin, F.; Wang, G. C.; Guo, S. Iridium-Based Multimetallic Porous Hollow Nanocrystals for Efficient Overall-Water-Splitting Catalysis. Adv. Mater. 2017, 29, 1703798.

(23) Fu, L.; Cheng, G.; Luo, W. Colloidal Synthesis of Monodisperse Trimetallic IrNiFe Nanoparticles as Highly Active Bifunctional Electrocatalysts for Acidic Overall Water Splitting. J. Mater. Chem. A 2017, 5, 24836-24841.

(24) Pi, Y.; Shao, Q.; Wang, P.; Guo, J.; Huang, X. General Formation of Monodisperse $\operatorname{IrM}(\mathrm{M}=\mathrm{Ni}, \mathrm{Co}, \mathrm{Fe})$ Bimetallic Nanoclusters as Bifunctional Electrocatalysts for Acidic Overall Water Splitting. Adv. Funct. Mater. 2017, 27, 1700886.

(25) Wang, J.; Ji, Y.; Yin, R.; Li, Y.; Shao, Q.; Huang, X. Transition Metal-Doped Ultrathin $\mathrm{RuO}_{2}$ Networked Nanowires for Efficient Overall Water Splitting across a Broad pH Range. J. Mater. Chem. A 2019, 7, 6411-6416. 
(26) Yuan, M.; Zhu, Y.; Deng, L.; Ming, R.; Zhang, A.; Li, W.; Chai, B.; Ren, Z. IrO2$\mathrm{TiO}_{2}$ Electrocatalysts for the Hydrogen Evolution Reaction in Acidic Water Electrolysis without Activation. New J. Chem. 2017, 41, 6152-6159. 